\title{
EFFECT OF PROTEIN LEVELS AND SOURCES ON GROWTH PERFORMANCE, SURVIVAL RATE, FEED UTILIZATION AND BODY CHEMICAL COMPOSITION OF BAYAD (BAGRUS BAJAD) FINGERLINGS
}

Athar M. Qurany, Sobhy M. Allam and Ramadan M. Abou-Zied

Animal Production Department, Faculty of Agriculture, Fayoum University, Egypt.

*Corresponding author: E-mail: atharmostafa90@gmail.com

\section{ABSTRACT}

A factorial experiment $2 \times 2$ was conducted to investigate the effect of protein level (30\% and $35 \%$ crude protein) with two protein source (50\% Animal protein, AP: $50 \%$ Plant protein, PP and 33\% AP: 67\% PP) on growth performance, feed utilization, body chemical composition and survival rate of Bayad (Bagrus bajad) fingerlings. Survival rate was within the range 96.67-100 \%. The highest growth parameters and the best FCR (lowest) were obtained with the diet contained on $(35 \% \mathrm{CP}$ and $50 \%$ AP: $50 \% \mathrm{PP})$. The diet contained (30\% CP and 33\% AP: $67 \%$ PP) had the lowest growth and the worst FCR than other treatment. However differences in growth parameters among diets contained on $(30 \% \mathrm{CP}, 50 \% \mathrm{AP}$ : $50 \% \mathrm{PP})$ and $(35 \% \mathrm{CP}, 33 \%$ AP: $67 \% \mathrm{PP})$ were insignificant $(\mathrm{P} \leq 0.05)$. Final body weight was progressively decreased with increasing plant protein under both protein level of diets. The improvement of growth performance and feed conversion ratio tested in diets containing higher levels of fish meal under both protein level of diets. The highest body protein content was with diet contained on (30\% CP and 33\% AP: $67 \%$ PP). The diet contained on (30\% CP and 50\% AP: $50 \% \mathrm{PP}$ ) had the lowest body protein content and the highest body ether extract content than other treatment. The lowest ether body extract content was with diet contained on (30\% CP and 33\% AP: $67 \%$ PP). It could be concluded that $35 \%$ and $30 \%$ crude protein level was the best under composition of diet ((50 AP: 50 PP) in terms of growth performance, feed utilization and economical evaluation under this experimental conditions.

Key words: protein level, protein source, animal protein, plant protein, growth performance, body chemical composition, feed conversion ratio, Bayad (Bagrus bajad).

\section{INTRODUCTION}

Bayad fish (Bagrus bajad Forsskal, 1775) is a benthic carnivorous feeder (bottom feeder) with high commercially importance (Malam and Magawata, 2010; Alhassan and Ansu-Darko, 2011 and El-Drawany and Elnagar, 2015) follow to the family Bagridae it was represented by thirty (30) genera and two hundred and ten (210) species. Bagridae commonly found throughout fresh- and brackish-water in Asia and Africa and only one genus, Bagrus, is endemic to Africa (Armbruster, 2011, Ng and Kottelat, 2013). Bayad fish (Bagrus bajed) is widely distributed in freshwater systems of Africa. It inhabits River Nile, Lake Chad, Niger and Senegal rivers, Lakes Mobuta and Tukana (Risch, 1986). Bagrus bajed $i s$ one of the most preferable freshwater fish food in Egypt.

The dietary protein requirement of a species is of prime importance in aquaculture, because feed protein influences growth of the fish and determines the

Fayoum J. Agric. Res. \& Dev., Vol. 34, No.2 July, 2020 
Athar M. Qurany et al.,

cost of feeding. The quantity as well as the quality of dietary protein is the determinants of the level of protein utilization by the fish. Therefore, studies on protein requirement are usually one of the first nutrient requirement experiments conducted when a new fish species is introduced in to aquaculture (Giri $\boldsymbol{e t}$ al., 2011). To quantify nutrient requirement, semi-purified or purified diets are generally used. Very often, practical diets are also formulated to quantify the protein requirement in different catfishes, Ictalurus puncatatus (Li et al., 2008), Clarias isheriensis (Fagbenro, 2007), hybrid catfish (Giri et al., 2003) and Mystus nemurus (Khan et al., 1993, 1996).

Fish meal (FM) is the dominant ingredient in commercially prepared diets for many fish species. As a consequence of rapid growth in fish and shellfish farming, FM prices have increased significantly in the past few years and are likely to increase further with continued growth in demand (Hardy and Tacon, 2002). As with general aquaculture nutrition, a priority area of major research is the reduction and possible elimination of FM and fish oil (Gatlin and Hardy 2002). The uncertain future of FM availability and its potential high cost has forced to investigate alternative protein sources of good nutritional quality, which are ideally readily available and more cost effective than FM. This will reduce production costs and create a good quality product suitable for any small or large-scale fish production system (Goda et al., 2007).

Soybean meal (SBM) is one of the best ingredients to replace FM (Lovell, 1988). Soybean meal is cost effective, readily available, high in protein content and has the best protein quality among plant protein feedstuffs used as alternative protein sources to FM in fish diet (Lovell, 1988 and Rumsey et al., 1993). However, considerable variations exist in the ability of different fish species to utilize soybean protein. Hypotheses explaining this lack of success include less than optimal amino acid (AA) balance in SBM protein and the presence of residual levels of trypsin inhibitors (Refstie, et al., 1997, 1998).

Protein is the main constituent of the fish body thus sufficient dietary supply is needed for optimum growth. Protein is the most expensive macronutrient in fish diet (Pillay, 1990). So, the amount of protein in the diet should be just enough for fish growth where the excess protein in fish diets may be wasteful and cause diets to be unnecessarily expensive (Ahmad, 2000). Reducing feeding costs could be a key factor for successful development of aquaculture.

The objective of the present study was, to evaluate the overall effects of feeding Bayad (Bagrus bajad) with diets containing different levels of crude protein (30\% and $35 \%)$ and varying protein source (fish meal and soybean meal) on growth performance, survival rate, feed utilization and fish body composition of Bayad fingerlings stocked in hapas located in earthen pond.

\section{MATERIAL AND METHODS}

The present study was carried out from 21 September 2019 to 30 November 2019 (70 days experimental period) in Fish Farm, Faculty of Agriculture, ElFayoum University, Egypt. This study was conducted to investigate the effect of protein level and source on growth performance, feed utilization, body chemical composition and survival rate of Bayad (Bagrus bajad Forsskal, 1775) fingerlings.

Fayoum J. Agric. Res. \& Dev., Vol. 34, No.2 July, 2020 
EFFECT OF PROTEIN LEVELS AND SOURCES ON

Fish- rearing conditions.

Bayad (Bagrus bajad) fingerlings were obtained from commercial farm in Kafr El-Sheikh Governorate. Fish were acclimated to farm conditions for 14 days before being randomly distributed into eight hapas located in earthen pond, in Fish Farm, Faculty of Agriculture, El-Fayoum University. Each hapa has an area of $4 \mathbf{X} 7 \mathrm{~m}$ with a water depth of $1 \mathrm{~m}$. Two hapas/ treatment. The distance between each treatment was $5 \mathrm{~m}$. Hapas were fixed in an earthen pond $(0.75$ Feddan areaX $1.5 \mathrm{~m}$ depth) with water level $1.3 \mathrm{~m}$. About $30 \%$ of water was changed with new fresh water every 3 days. Fish were held under natural photoperiod condition throughout the experimental period. The average water quality criteria in the trial are presented in Table (1). At the end of experiment, 5 fish from hapas were randomly taken for the determination of body chemical analysis.

Table (1). An averages of water quality parameters during the experimental period.

\begin{tabular}{|l|c|}
\hline \multicolumn{1}{|c|}{ Items } & Measurement \\
\hline Water temperature ${ }^{\circ} \mathrm{C}$ & $24.5-26$ \\
\hline Water salinity, $\mathrm{mg} / \mathrm{l}$ & $0.1-0.3$ \\
\hline $\mathrm{pH}$ & $6.9-7.3$ \\
\hline Dissolved oxygen $\mathrm{mg} / \mathrm{l}$ & $6.2-7.4$ \\
\hline Ammonia $\mathrm{mg} / \mathrm{l}$ & 0.03 \\
\hline
\end{tabular}

Experimental design.

This trial consisted of two factors (factorial design, 2X2), the first factor was protein level (30\% and 35\% crude protein) with two protein source $(50 \%$ Animal protein, AP: 50\% Plant protein, PP and 33\% AP: 67\% PP). Fish fingerlings of $31.86 \pm 0.34 \mathrm{~g}$ initial body weight. Fish were randomly distributed and stocked at 15 fingerlings/ hapa in 8 hapas. The experimental treatments were duplicated.

\section{Diets and feeding}

Diets were formulated based on fish meal as animal protein source and soybean meal as plant protein source. Fish oil was added as the major dietary lipid source to the all experimental diets. Wheat flour and molasses were used as sources of carbohydrate. The diets formulated to be almost containing $30 \%$ and $35 \%$ crude protein, diets were hand made. The experimental diets were prepared by mixing dry ingredients with water. Then pelleted diet was produced through a meat mincer with a $1.5 \mathrm{~mm}$ diameter. The pellets were dried by air and stored at $-20^{\circ} \mathrm{C}$ until use. Ingredient composition of the diets is presented in (Table 2). Feed was offered by hand at two meals/day (9:00 and 14:00 h) for 6 days a week at 5\% of body weight daily and the amount of diets were readjusted after each weighing (every 15 days). Feed consumption was recorded daily. Initial and final data for growth performance was obtained by sampling all the experimental fish.

Fayoum J. Agric. Res. \& Dev., Vol. 34, No.2 July, 2020 
Athar M. Qurany et al.,

Table (2). Ingredients and chemical composition of the experimental diets

\begin{tabular}{|l|c|c|c|c|}
\hline \multicolumn{1}{|c|}{ Protein level (\%) } & $\mathbf{3 0}$ & $\mathbf{3 0}$ & $\mathbf{3 5}$ & $\mathbf{3 5}$ \\
\hline Protein sources (AP: PP) & $\mathbf{5 0 : 5 0}$ & $\mathbf{3 3 : 6 7}$ & $\mathbf{5 0 : 5 0}$ & $\mathbf{3 3 : 6 7}$ \\
\hline Ingredients, \% & \multicolumn{4}{|l|}{} \\
\hline Fish meal & 21.2 & 14.2 & 24.5 & 16.5 \\
\hline Soybean meal & 23 & 35 & 32 & 46 \\
\hline Wheat flour & 48.3 & 43.3 & 36 & 30 \\
\hline Molasses & 2 & 2 & 2 & 2 \\
\hline Fish oil & 5 & 5 & 5 & 5 \\
\hline Vit \& Min. * & 0.5 & 0.5 & 0.5 & 0.5 \\
\hline Total & 100 & 100 & 100 & 100 \\
\hline Chemical composition & $\mathbf{( a s}$ fed, \%) & & \\
\hline Dry matter, DM & 89.44 & 89.76 & 90.10 & 90.43 \\
\hline Crude protein, CP & 29.85 & 30.32 & 34.28 & 34.89 \\
\hline Ether extract, EE & 7.91 & 7.45 & 8.09 & 7.55 \\
\hline Crude fiber, CF & 3.01 & 3.69 & 3.43 & 4.23 \\
\hline Ash & 6.60 & 5.99 & 7.61 & 6.93 \\
\hline Nitrogen free extract. NFE** & 42.07 & 42.31 & 36.69 & 36.83 \\
\hline GE, kcal/g*** & 4.283 & 4.304 & 4.346 & 4.368 \\
\hline Prices of Kg, L.E & 8.87 & 7.73 & 12.53 & 10.70 \\
\hline
\end{tabular}

AP, Animal protein. PP, Plant protein

* Vitamins and minerals mixture each $3 \mathrm{~kg}$ of mixture contains: 12000000 IU Vit. A, 2000000 IU Vit. D, 10000 mg Vit. E, 2000 mg Vit. K, 1000 mg Vit. B, 5000 mg Vit. $B_{2}, 1500 \mathrm{mg}$ Vit. $\mathrm{B}_{6}, 10 \mathrm{mg}$ Vit. $\mathrm{B}_{12}, 50 \mathrm{mg}$ Biotin, $10000 \mathrm{mg}$ Pantothenic acid, $30000 \mathrm{mg}$ Nicotinic acid, $1000 \mathrm{mg}$ Folic acid, $60000 \mathrm{mg}$ Manganese, 50000 mg Zinc, 30000 mg Iron, 10000 mg Copper, 1000 mg Iodine,100 mg Selenium, $100 \mathrm{mg}$ Cobalt, add to $3 \mathrm{~kg}$ carrier $\left(\mathrm{CaCo}_{3}\right)$.

** Calculated by differences.

*** Calculated according to NRC, 1993.

\section{Parameters measurements}

At the end of the experiment, growth performance, survival rate and feed utilization were calculated as follows:

- Weight gain $(\mathrm{g})$ = final weight, $\mathrm{g}$ - initial weight, $\mathrm{g}$.

- Average daily gain $(\mathrm{g})=$ average weight gain, $\mathrm{g} /$ experimental period, day.

- Specific growth rate $(\mathrm{SGR}, \%)=[(\ln$ final weight $-\ln$ initial weight $) /$ period in days] $\times 100$, where $\ln$ is the natural $\log$.

- Feed conversion ratio $(\mathrm{FCR})=$ feed intake, g/ weight gain, $\mathrm{g}$.

- Protein efficiency ratio $(\mathrm{PER})=$ weight gain, $\mathrm{g} /$ protein intake, $\mathrm{g}$.

- Protein productive value $(\mathrm{PPV}, \%)=($ retained protein, $\mathrm{g} /$ protein intake, $\mathrm{g}) \times 100$.

- Energy efficiency ratio $($ EER) $=$ weight gain, g/ energy intake, Kcal.

- Energy productive value $(\mathrm{EPV}, \%)=$ (retained energy, Kcal/ energy intake, Kcal) $\times 100$.

- Survival rate, $\%=$ (number of fish at end/ number of fish at start $) \times 100$.

Fayoum J. Agric. Res. \& Dev., Vol. 34, No.2 July, 2020 


\section{Chemical analysis}

Diets used and body composition were analyzed for their proximate composition in triplicates following the methods described by AOAC (2012). Gross energy was calculated according to (NRC, 1993) for formulated diets the factors $5.64,9.44$ and $4.11 \mathrm{Kcal} / \mathrm{g}$ for protein, fat and carbohydrates, respectively, for fish 5.5 and $9.5 \mathrm{Kcal} / \mathrm{g}$ for protein and fat, respectively.

Statistical analysis.

The data were analyzed by general linear model and significant differences were determined by Duncan waller Multiple Range Test at 5\% level using SPSS Statistical Package Program (SPSS, 2008) 17, released version.

\section{RESULTS AND DISCUSSION}

\section{Water quality.}

water quality parameters was shown in Table (1) this parametres ranged between (24.5-26 $\left.{ }^{\circ} \mathrm{C}\right)$, Water salinity, $\mathrm{mg} / 1$ (0.1-0.3 ppt), $\mathrm{pH}$ (6.9-7.3), Dissolved oxygen $\mathrm{mg} / \mathrm{l}(6.2-7.4 \mathrm{mg} / \mathrm{l})$ and Ammonia $\mathrm{mg} / \mathrm{l}(0.03-0.1 \mathrm{mg} / \mathrm{l})$. Bayad fiah are one of warm water fish so this values of paramteres are ssuited and fall between the acceptable range for Bayad fish growth and health according to (Auta, 1993 and Adakole, 2000).

\section{Growth performance and survival rate of Bayad (Bagrus bajad).}

Results of growth performance parameters and survival rate of fish fed on the different protein levels are shown in Table (3).

There was no significant difference in the initial average body weight of the fish among treatments. Survival rate was $98.33 \%$, with insignificant differences were observed. The results showed that significant differences $(\mathrm{P} \leq 0.05)$ were obtained in final weight, total gain, daily gain and SGR. Results of growth performance parameters were highest with fish fed on 35\% crude protein (CP) diet compared with $30 \% \mathrm{CP}$ diet. Results show that final weight $(\mathrm{g})$, total gain in weight $(\mathrm{g})$, daily gain $(\mathrm{g})$ and SGR\% for $35 \% \mathrm{CP}$ diet were $65.62,33.79,0.483$ and 1.030 , respectively. The same growth parameters for $30 \% \mathrm{CP}$ diet were 55.77, $23.88,0.341$ and 0.789 , respectively. These results indicated that the best growth rate for fish was obtained at feeding on $35 \% \mathrm{CP}$ diet under experimental conditions.

Table (3). Effect of protein level on growth performance and survival rate of Bayad (Bagrus bajad).

\begin{tabular}{|l|c|c|c|}
\hline \multirow{2}{*}{ Items } & \multicolumn{2}{|c|}{ Protein level (\%) } & \multirow{2}{*}{ SED $^{*}$} \\
\cline { 2 - 3 } & $\mathbf{3 0}$ & $\mathbf{3 5}$ & \\
\hline Initial weight, g/fish & 31.89 & 31.83 & 0.7368 \\
\hline Final weight, g/fish & $55.77^{\mathrm{b}}$ & $65.62^{\mathrm{a}}$ & 4.7261 \\
\hline Total gain, g/fish & $23.88^{\mathrm{b}}$ & $33.79^{\mathrm{a}}$ & 4.4446 \\
\hline Daily gain, g/fish/day & $0.341^{\mathrm{b}}$ & $0.483^{\mathrm{a}}$ & 0.6324 \\
\hline SGR, \%/day & $0.789^{\mathrm{b}}$ & $1.030^{\mathrm{a}}$ & 0.1048 \\
\hline Survival rate, \% & 98.33 & 98.33 & 2.358 \\
\hline
\end{tabular}

- (a and b) Average in the same row having different superscripts are differ significantly $(\mathbf{P} \leq \mathbf{0 . 0 5})$.

* SED is the standard error of difference

Fayoum J. Agric. Res. \& Dev., Vol. 34, No.2 July, 2020 
Athar M. Qurany et al.,

The growth parameters values increased with increasing the protein diet, this agree with results of other studies are different in various species. $\mathbf{N g} \boldsymbol{e t} \boldsymbol{a l}$. (2001) reported that, percentage weight gain of bagrid catfish (Mystus nemurus) increased almost linearly with increasing dietary protein content up to about 410 $\mathrm{g} / \mathrm{kg}$ diet, reached a plateau, and then decreased at protein levels beyond $471 \mathrm{~g} / \mathrm{kg}$ diet. A similar increase in weight gain of Mystus nemurus with increasing protein levels $(270-420 \mathrm{~g} / \mathrm{kg}$ diet) and growth depression when the protein level further increased to $470 \mathrm{~g} / \mathrm{kg}$ diet and beyond were also observed by (Khan $\boldsymbol{e t}$ al., 1993). In agreement with the present study Giri et al. (2011) studied the effect of different levels of dietary protein, 25, 30, 35, 40 and 45\% of bagrid catfish Horabagrus brachysoma. The highest body weight gain and specific growth rate were observed in fish fed 35\% protein diet. Also, Keremah and Beregha, (2014) reported that, the growth indices (weight gain, percent weight gain and specific growth rate) increased with increasing fish meal (FM) dietary protein source from $25 \%$ to $35 \%$ and then declined at $40 \% \mathrm{CP}$. This observation suggested that a $35 \%$ high quality protein ration with FM would probably provide the needed protein by African catfish (Clarias gariepinus) fingerlings for good growth performance (Keremah and Beregha, 2014).

Feed constitutes $60-70 \%$ of total investment in aquaculture. Any reduction in dietary protein level without affecting fish growth can substantially reduce the cost of fish feed (Jamabo and Alfred-Ockiya, 2008). Dietary protein is used by fish for growth, energy and body maintenance (Kausshik and Medale, 1994). Protein requirement for maximum growth of any species of fish is a step forward in developing cost effective feed for fish farming and this has to do with determining the optimum amount required to produce maximum growth rate (Sang-Min and Tae-Jun, 2005).

\section{Feed utilization of of Bayad (Bagrus bajad).}

As shown in Table (4). The results showed that insignificant differences $(\mathrm{P} \leq 0.05)$ were obtained in FCR, PER and EER between treatments except the feed intake. Feed intake values were highest with diet containing $(35 \% \mathrm{CP})$. Also, the best FCR was recorded with diet containing (35\% CP). The same trend was observed with PER and EER, but FCR, PER and EER values obtained insignificant differences $(\mathrm{P} \leq 0.05)$.

Table (4). Effect of protein level on feed utilization of Bayad (Bagrus bajad).

\begin{tabular}{|l|c|c|c|}
\hline \multirow{2}{*}{ Items } & \multicolumn{2}{|c|}{ Protein level (\%) } & \multirow{2}{*}{ SED $^{*}$} \\
\cline { 2 - 3 } & $\mathbf{3 0}$ & $\mathbf{3 5}$ & \\
\hline Feed intake, g/fish & $107.72^{\mathrm{b}}$ & $126.73^{\mathrm{a}}$ & 7.5562 \\
\hline FCR & 3.37 & 3.98 & 0.4722 \\
\hline PER & 0.74 & 0.76 & 0.0836 \\
\hline EER & 0.22 & 0.51 & 0.00057 \\
\hline
\end{tabular}

- (a and b) Average in the same row having different superscripts are differ significantly $(\mathrm{P} \leq 0.05)$.

* SED is the standard error of difference

Fayoum J. Agric. Res. \& Dev., Vol. 34, No.2 July, 2020 
These results similar to that of $\mathbf{N g}$ et al. (2001) who reported that, the efficiency of protein utilization as depicted by PER generally did not differ significantly between fish fed with dietary protein levels of $202-410 \mathrm{~g} / \mathrm{kg}$ diet of bagrid catfish (Mystus nemurus). Martinez-Palacios et al. (2007) in Menidia ester also observed decrease in daily feed intake in response to dietary protein level below $300 \mathrm{~g} / \mathrm{kg}$ diet. In agreement with Agbo et al. (2014) studied the effects of dietary protein levels $(32.1 \%, 34.6 \%, 42.8 \%$, and $47.1 \%)$ using fish meal/soybean meal as protein sources on growth performance of claroteid catfish, Chrysichthys nigrodigitatus, fingerlings. Results after ten weeks of feeding showed an increase in protein efficiency ratio with increasing levels of dietary protein up to $42.8 \%$ $(\mathrm{P}<0.05)$, but there were no significant differences between the treatments. Feed conversion ratio (FCR) reduced as dietary protein level increased, with the minimum FCR in the $42.8 \%$ protein diet.

Growth performance and survival rate of Bayad (Bagrus bajad) fed different animal and plant protein sources.

Results of growth performance parameters and survival rate of fish fed on the different protein source of diet are shown in Table (5).

There was no significant difference in the initial average body weight of the fish among treatments. Survival rate was within the range $96.67-100 \%$, with insignificant differences were observed. The results showed that significant differences $(\mathrm{P} \leq 0.05)$ were obtained in final weight, total gain, daily gain and SGR. Results of growth performance parameters were highest with fish fed on diet containing (50\% animal protein (AP): $50 \%$ plant protein (PP)) compared with diet containing (33\% AP: 67\% PP). These results indicated that the best growth rate for fish was obtained at feeding on diet containing (50\% AP: $50 \%$ PP) under experimental conditions.

These results led to believe that fish meal presented in the diet resulted in improving growth rate as it has better essential amino acid profile and a good source of essential minerals and vitamins.

Table (5). Effect of protein sources on growth performance and survival rate of Bayad (Bagrus bajad).

\begin{tabular}{|l|c|c|c|}
\hline \multirow{2}{*}{ Items } & \multicolumn{2}{|c|}{ Protein sources } & \multirow{2}{*}{ SED } \\
\cline { 2 - 3 } & 50AP: 50 PP & 33AP: 67PP & \\
\hline Initial weight, g/fish & 31.91 & 31.81 & 0.7362 \\
\hline Final weight, g/fish & $65.87^{\mathrm{a}}$ & $55.53^{\mathrm{b}}$ & 4.5502 \\
\hline Total gain, g/fish & $33.96^{\mathrm{a}}$ & $23.72^{\mathrm{b}}$ & 4.3220 \\
\hline Daily gain, g/fish/day & $0.485^{\mathrm{a}}$ & $0.339^{\mathrm{b}}$ & 0.0632 \\
\hline SGR, \%/day & $1.032^{\mathrm{a}}$ & $0.787^{\mathrm{b}}$ & 0.1024 \\
\hline Survival rate, \% & 100 & 96.67 & 1.9254 \\
\hline
\end{tabular}

- (a and b) Average in the same row having different superscripts are differ significantly $(\mathrm{P} \leq 0.05)$.

* SED is the standard error of difference.

AP, Animal protein. PP, Plant protein.

These results similar to that of Kokou et al. (2012) studied the effects of partial fish meal replacement by a bioprocessed soy product (BS) in juvenile

Fayoum J. Agric. Res. \& Dev., Vol. 34, No.2 July, 2020 
Athar M. Qurany et al.,

gilthead Sea bream. Final fish weight did not significantly differ between the FM and the BS 20 groups, but decreased gradually at higher BS inclusion. However, weight gain and SGR were not significantly different among FM, BS 20 and BS 40 diets, but decreased significantly at the $60 \%$ BS inclusion level $(\mathrm{P}<0.001)$.

These results disagree with the results of Goda $\boldsymbol{e t}$ al. (2007) studied the effect of totally or partially replacing fish meal by alternative protein sources on growth of African catfish (Clarias gariepinus). Final body weight and specific growth rate of the fish fed diets containing SBM (75\% and 100\%) were all higher, but not significantly different than those for fish fed the control diet (100 FM). Also, Venou et al. (2006) studied the effects of soybean meal inclusion on the performance of gilthead Sea bream. Increasing the level of SBM had no significant effect on SGR.

Feed utilization of of Bayad (Bagrus bajad).

As shown in Table (6). The results showed that significant differences $(\mathrm{P} \leq 0.05)$ were obtained in all feed utilization parameters between treatments, except the feed intake. The highest feed intake was observed with fish fed on diet containing (50\% AP: $50 \%$ PP), with insignificant differences among treatments. The best FCR (lowest) was recorded with fish fed on diet containing (50\% AP: 50\% PP). The same trend was observed with PER and EER.

These results similar to that of Venou et al. (2006) studied the effects of soybean meal inclusion on the performance of gilthead Sea bream. Inclusion level of soybean meal increased significantly FCR. Soybean meal inclusion decreased PER significantly.

These results disagree with the results of Kokou $\boldsymbol{e t}$ al. (2012) studied the effects of partial fish meal replacement by a bioprocessed soy product (BS) in juvenile gilthead Sea bream. Feed intake was positively influenced by the level of BS, especially at the higher levels of inclusion. PER, indicated that some differentiation among groups started from the $40 \%$ BS inclusion level.

Table (6). Effect of Protein sources on feed utilization of Bayad (Bagrus bajad).

\begin{tabular}{|l|c|c|c|}
\hline \multirow{2}{*}{ Items } & \multicolumn{2}{|c|}{ Protein sources } & \multirow{2}{*}{ SED* } \\
\cline { 2 - 3 } & 50AP: 50 PP & 33AP: 67PP & \\
\hline Feed intake, g/fish & 124.80 & 109.64 & 8.8896 \\
\hline FCR & $3.72^{\mathrm{b}}$ & $4.78^{\mathrm{a}}$ & 0.40804 \\
\hline PER & $0.844^{\mathrm{a}}$ & $0.651^{\mathrm{b}}$ & 0.0287 \\
\hline EER & $0.063^{\mathrm{a}}$ & $0.049^{\mathrm{b}}$ & 0.000452 \\
\hline
\end{tabular}

- (a and b) Average in the same row having different superscripts are differ significantly $(\mathrm{P} \leq 0.05)$.

* SED is the standard error of difference

AP, Animal protein. PP, Plant protein

Effect of protein levels and sources on growth performance, feed utilization, body chemical composition and survival rate of Bayad (Bagrus bajad) fingerlings.

Growth performance and survival rate of Bayad (Bagrus bajad).

Fayoum J. Agric. Res. \& Dev., Vol. 34, No.2 July, 2020 
EFFECT OF PROTEIN LEVELS AND SOURCES ON

Results of growth performance parameters and survival rate of fish fed on the different protein level and source of diets are shown in Table (7).

Table (7). Effect of protein level and source on growth performance and survival rate of Bayad (Bagrus bajad).

\begin{tabular}{|l|c|c|c|c|c|}
\hline \multirow{2}{*}{ Protein level } & \multicolumn{2}{|c|}{ 30\% CP } & \multicolumn{2}{c|}{ 35\% CP } & \multirow{2}{*}{ SED* } \\
\cline { 2 - 5 } \multicolumn{1}{c|}{ Protein sources } & 50 AP: & 33 AP: & 50 AP: & 33 AP: & \\
\hline Initial weight, g & 32.02 & 31.77 & 31.80 & 31.85 & 1.269 \\
\hline Final weight, g & $61.77^{\mathrm{b}}$ & $49.77^{\mathrm{c}}$ & $69.96^{\mathrm{a}}$ & $61.29^{\mathrm{b}}$ & 3.492 \\
\hline Total gain, g/fish & $29.76^{\mathrm{b}}$ & $18.01^{\mathrm{c}}$ & $38.16^{\mathrm{a}}$ & $29.44^{\mathrm{b}}$ & 2.391 \\
\hline Daily gain, g/fish/ day & $0.425^{\mathrm{b}}$ & $0.257^{\mathrm{c}}$ & $0.546^{\mathrm{a}}$ & $0.421^{\mathrm{b}}$ & 0.034 \\
\hline SGR, \%/day & $0.938^{\mathrm{b}}$ & $0.641^{\mathrm{c}}$ & $1.126^{\mathrm{a}}$ & $0.934^{\mathrm{b}}$ & 0.037 \\
\hline Survival rate, \% & 100 & 96.67 & 100 & 96.67 & 3.335 \\
\hline
\end{tabular}

- $(\mathrm{a}, \mathrm{b}, \mathrm{c})$ Average in the same row having different superscripts are differ significantly $(\mathrm{P} \leq 0.05)$. * SED is the standard error of difference

$\mathrm{CP}$, Crude protein. AP, Animal protein. PP, Plant protein.

There was no significant difference in the initial average body weight of the fish among treatments. Survival rate was within the range $96.67-100 \%$, with insignificant differences were observed. The results showed that significant differences $(\mathrm{P} \leq 0.05)$ were obtained in final weight, total gain, daily gain and SGR. The highest values obtained with the diet contained on (35\% CP and 50\% AP: $50 \%$ PP). The diet contained on (30\% CP and 33\% AP: 67\% PP) had the lowest value than other treatment. However differences in growth parameters among diets contained on (30\% CP, 50\% AP: 50\% PP) and (35\% CP, 33\% AP: $67 \%$ PP) were insignificant $(\mathrm{P} \leq 0.05)$. Final body weight was progressively decreased with increasing PP under both protein level of diets. The improvement of all growth performance parameters tested in diets containing higher levels of fish meal under both protein level of diets.

These results led to believe that the fish meal presented in the diet contain a good smell which attract the fish to consume the diet and resulted in improving growth rate as it has better essential amino acid profile and a good source of essential minerals and vitamins.

These results similar to that of Agbo et al. (2014) studied the effects of dietary protein levels $(32.1 \%, 34.6 \%, 42.8 \%$, and $47.1 \%)$ using fish meal/soybean meal as protein sources on growth performance of claroteid catfish, Chrysichthys nigrodigitatus, fingerlings. Results after ten weeks of feeding showed an increase in body weight gain and specific growth rate with increasing levels of dietary protein up to $42.8 \%(\mathrm{P}<0.05)$ but a decline at $47.1 \%$ CP. Diyaware et al. (2009) explained that, the increases in growth rate and nutrient utilization with increase in dietary protein levels for hybrid catfish. Also, similar to the observations of Jamabo and Alfred-Ockiya (2008) on Heterobranchus fingerlings, Fagbenro et al. (1992) for H. bidorsalis fingerlings and Obasa and Faturoti (2000) for Cryptocoryne walker.

Fayoum J. Agric. Res. \& Dev., Vol. 34, No.2 July, 2020 
Athar M. Qurany et al.,

Soybean meal (SBM) is one of the best ingredients to replace FM (Lovell, 1988). Soybean meal is cost effective, readily available, high in protein content and has the best protein quality among plant protein feedstuffs used as alternative protein sources to FM in fish diet (Lovell, 1988 and Rumsey et al., 1993). Goda et al. (2007) clearly demonstrated that SBM can totally replace FM in practical diet for African catfish.

Feed utilization of of Bayad (Bagrus bajad).

Results of feed utilization of fish fed on the different protein level and source of diets are shown in Table (8). Feed intake had significantly different between treatments $(\mathrm{P} \leq 0.05)$ and value was highest with diet contained on $(35 \% \mathrm{CP}$ and $50 \%$ AP: $50 \%$ PP). Feed intake values were lowest with diet contained on $(30 \%$ $\mathrm{CP}$ and $33 \%$ AP: $67 \%$ PP). FCR values were significantly different between treatments $(\mathrm{P} \leq 0.05)$, the best FCR (lowest) was recorded with diet contained on (35\% CP and 50\% AP: 50\% PP). The worst FCR was recorded with diet containing on $(30 \% \mathrm{CP}$ and $33 \%$ AP: $67 \%$ PP). The improvements in FCR for groups fed higher levels of fish meal under both protein level of diets. The diets contained on (30 and 35\% CP with 50\% AP: 50\% PP) had the highest PER value. However differences in PER among diets contained on (30 and 35\% CP with 50\% AP: 50\% PP) and among (30 and 35\% CP with 33\% AP: 67\% PP) were insignificant $(\mathrm{P} \leq 0.05)$. The highest EER value was recorded with diet containing on $(35 \% \mathrm{CP}$ and $50 \%$ AP: $50 \%$ PP).

The quantity and quality of feed demands for routine maintenance and activity to a large extent will determine the effect of food consumed on growth (Warren and Davis, 1967). Food utilization expressed as FCR is known to be affected by body weight (Pandian, 1967), ration, size (Condrey, 1982) and temperature (Smith, 1989).

Table (8). Effect of interaction between protein level and source on feed utilization of Bayad (Bagrus bajad).

\begin{tabular}{|l|c|c|c|c|c|}
\hline \multirow{2}{*}{ Protein level } & \multicolumn{2}{|c|}{ 30\% CP } & \multicolumn{2}{c|}{ 35\% CP } & \multirow{2}{*}{ SED* } \\
\cline { 2 - 5 } Protein sources & $\mathbf{5 0}$ AP: & 33 AP: & 50 AP: & 33 AP: & \\
\hline Feed intake, g/fish & $119.35^{\mathrm{a}}$ & $96.08^{\mathrm{b}}$ & $130.26^{\mathrm{a}}$ & $123.20^{\mathrm{a}}$ & 4.845 \\
\hline FCR & $4.02^{\mathrm{bc}}$ & $5.36^{\mathrm{a}}$ & $3.42^{\mathrm{c}}$ & $4.19^{\mathrm{b}}$ & 0.261 \\
\hline PER & $0.835^{\mathrm{a}}$ & $0.618^{\mathrm{b}}$ & $0.854^{\mathrm{a}}$ & $0.684^{\mathrm{b}}$ & 0.036 \\
\hline EER & $0.058^{\mathrm{b}}$ & $0.044^{\mathrm{c}}$ & $0.068^{\mathrm{a}}$ & $0.055^{\mathrm{b}}$ & 0.002 \\
\hline
\end{tabular}

- $(a, b, c)$ Average in the same row having different superscripts are differ significantly

$(\mathrm{P} \leq 0.05) . \quad * \mathrm{SED}$ is the standard error of difference

$\mathrm{CP}$, Crude protein. AP, Animal protein. PP, Plant protein.

These results similar to that for African catfish (Clarias gariepinus) of Keremah and Beregha (2014) explained that, the higher FCR for 25 and 30\% CP diets indicated that food utilization became less efficient and apparently fish did not consume the amount of protein needed for optimum growth (Anguas-Vélez et al., 2000). However, FCR became lower at higher levels of dietary protein (35$45 \%$ CP) showing similarity (3.89-4.14) but improved food utilization. The FCR

Fayoum J. Agric. Res. \& Dev., Vol. 34, No.2 July, 2020 
values obtained appeared to decrease with increase in protein level within the range of $25-40 \% \mathrm{CP}$.

These results similar to that of Keremah and Beregha (2014) who reported that, protein efficiency ratio values were similar especially among 30-45\% dietary protein levels tested. Also, these results corroborated with the findings of Mohanty and Samantaray (1996) for snakehead Channa striata fry and Lochmann and Phillips (1994) for gold fish Carassius auratus juveniles using casein or other protein sources. It appeared that protein was used with rather low efficiency independently of the dietary protein level (Anguas-Vélez et al., 2000). Giri et al. (2011) studied the effect of different levels of dietary protein, 25, 30, 35, 40 and $45 \%$ of bagrid catfish Horabagrus brachysoma. The highest protein efficiency ratio (PER), and the lowest feed conversion ratio (FCR) were observed in fish fed $35 \%$ protein diet.

The nutritional value of a protein source is a function of its digestibility and amino acids make up to influence feed utilization and growth (Otisi and Ufodike, 1986). Fish meal satisfies this requirement and is also a rich source of energy and minerals.

Giri et al. (2011) daily dry matter intake by 30-45 CP fed fishes did not vary significantly $(\mathrm{P}>0.05)$. Therefore, another reason for inferior growth performance of fish fed on the 25 and $30 \mathrm{CP}$ diets could be because of higher levels of carbohydrates in their diets, which supports to the observations of Jantrarotai $\boldsymbol{e t}$ al. (1994) in hybrid catfish, Giri et al. (2000) in Clarias batrachus, Giri et al. (2003) in hybrid catfish and Martinez-Palacios et al. (2007) in Mexican silverside, Menidia estor. The high-carbohydrate diet decreases enzyme activities and digestibility of carbohydrate and protein, which culminated in retarded growth in fish (Ufodike and Matty, 1983).

Fish body chemical composition of Bayad (Bagrus bajad).

Fish body chemical composition and energy content of Bayad (Bagrus bajad) at the end of the expriement are shown in Table (9).

The results showed that significant differences $(\mathrm{P} \leq 0.05)$ were obtained in moisture, $\mathrm{CP}, \mathrm{EE}$ and $\mathrm{GE}$ of body composition at the end of the experimental period, however ash had insignificant differences. The highest moisture content was with diet contained on (35\% CP and 50\% AP: 50\% PP). The highest protein content was with diet contained on (30\% CP and 33\% AP: 67\% PP). The diet contained on (30\% CP and 50\% AP: $50 \%$ PP) had the lowest protein content and the highest EE content than other treatment. The lowest EE content was with diet contained on (30\% CP and 33\% AP: $67 \%$ PP). The highest GE value was with diet contained on (30\% CP and 50\% AP: $50 \%$ PP).

These results similar to that of $\mathbf{N g}$ et al. (2001) who reported that, the various dietary protein levels significantly affected final whole body lipid composition of bagrid catfish (Mystus nemurus). Body lipid contents of fish fed with lower protein diets (202-295 g/kg diet) were significantly higher compared with fish fed with higher protein diets. Several studies have shown that body fat in catfish increases when dietary protein concentration decreases as protein/energy ratio decreases (Reis et al. 1989 and $\mathrm{Li}$ and Lovell, 1992). This is contrary to the levels of body 
Athar M. Qurany et al.,

lipid reported for $M$. nemurus by Khan et al. (1993), which saw higher lipid levels in fish fed with the 470 and $500 \mathrm{~g} / \mathrm{kg}$ protein diets which they attributed to the possibility of the excess dietary protein being deaminated and stored as body fat. Studies with other fish species have found that with increasing dietary protein, the lipid content of the fish carcass decreased (Jauncey, 1982 and Martinez-Palacios et al. 1996), which is consistent with the results of the present study.

Table (9). Effect of interaction between protein level and source on fish body chemical composition and energy content of Bayad (Bagrus bajad).

\begin{tabular}{|c|c|c|c|c|c|}
\hline \multirow{2}{*}{$\begin{array}{l}\text { Protein level } \\
\text { Protein source }\end{array}$} & \multicolumn{2}{|c|}{$30 \% \mathrm{CP}$} & \multicolumn{2}{|c|}{$35 \% \mathrm{CP}$} & \multirow[t]{2}{*}{ SED* } \\
\hline & $\begin{array}{l}\text { 50 AP: } \\
50 \text { PP }\end{array}$ & $\begin{array}{l}33 \text { AP: } \\
67 \text { PP }\end{array}$ & $\begin{array}{c}50 \text { AP: } \\
50 \text { PP }\end{array}$ & $\begin{array}{l}33 \text { AP: } \\
67 \text { PP }\end{array}$ & \\
\hline Moisture, \% & $77.78^{b}$ & $79.39^{\mathrm{a}}$ & $80.14^{\mathrm{a}}$ & $78.18^{b}$ & 0.300 \\
\hline Crude protein $(\mathrm{CP}), \%$ & $69.22^{b}$ & $73.69^{\mathrm{a}}$ & $71.14^{\mathrm{ab}}$ & $72.06^{\mathrm{ab}}$ & 1.041 \\
\hline Ether extract (EE), \% & $11.71^{\mathrm{a}}$ & $5.91^{\mathrm{c}}$ & $7.84^{\mathrm{b}}$ & $8.59^{b}$ & 0.589 \\
\hline Ash, $\%$ & 18.08 & 18.41 & 19.53 & 17.86 & 1.130 \\
\hline Gross energy (GE), kcal/g & $4.919^{\mathrm{a}}$ & $4.614^{\mathrm{b}}$ & $4.657^{b}$ & $4.779^{\mathrm{ab}}$ & 0.071 \\
\hline
\end{tabular}

- $(a, b, c)$ Average in the same row having different superscripts are differ significantly

$(\mathrm{P} \leq 0.05) . \quad *$ SED is the standard error of difference

$\mathrm{CP}$, Crude protein. AP, Animal protein. PP, Plant protein.

In contrast, Ng et al. (2001) found that, the carcass protein content of $M$. nemurus tended to increase with increasing dietary protein levels of $202-471 \mathrm{~g} / \mathrm{kg}$ diet but these changes were not significant. Also, Khan et al. (1993) reported that the whole body protein of $M$. nemurus increased significantly with increasing dietary protein levels up to $420 \mathrm{~g} / \mathrm{kg}$ diet and then decreased when fish were fed with higher protein levels. Moreover, Giri et al. (2011) found that, the carcass protein content of $H$. brachysoma did not vary $(\mathrm{P}>0.05)$ in response to dietary protein levels. Other researchers have reported no significant changes in fish body protein content when fish were fed with various levels of dietary protein (Moore $\boldsymbol{e t}$ al., 1988). There does not seem to be a consistent trend concerning the dependence of the protein content of fish carcasses on the protein level of diets fed to fish as reported in the current literature.

Shearer (1994) pointed out that the proximate composition of fish is influenced by both endogenous factors such as fish size and sex as well as exogenous factors such as diet composition and the culture environment. This may partly explain the lack of agreement concerning the influence of various levels of dietary protein on the protein content of the fish body.

These results disagree with the results of Goda et al. (2007) studied the effect of totally or partially replacing fish meal by alternative protein sources on growth of African catfish (Clarias gariepinus). Concerning whole body composition, there were no significant differences in ash and gross energy content of whole-body among fish, while fish fed diet SBM-100\% recorded significantly lower moisture content compared with the control diet (100 FM). Also fish fed diets SBM-100\% recorded higher lipid and gross energy contents compared with the control diet.

Economic Evaluation

Fayoum J. Agric. Res. \& Dev., Vol. 34, No.2 July, 2020 
Table (10). Present economical evaluation of protein level $(30 \%$ and $35 \%$ crude protein) with two protein source (50\% Animal protein, AP: 50\% Plant protein, PP and 33\% AP: 67\% PP) throughout the experimental period (70 days) on bayad feeding. It is well known that feeding cost in fish production is about $50 \%$ and more of the total production costs as declared by. Under the present experimental condition, all other costs are constant; therefore, the feeding cost to produce one Kilogram of fresh body weight could be used as a measure to compare between the tested diets. It is expected that, future of aquaculture developments will be in the form of semi-intensive or intensive culture systems which and these require appreciable inputs of fertilizers and/ or artificial feeds.

The results of the current study demonstrated that the $35 \%$ protein level is more economical in bayad aquaculture

Net returned of bayad were better for the $35 \%$ treatment (50 AP: 50 PP) which was 1.20) but the worst was $30 \%$ ((33 AP: $67 \mathrm{PP})$ which was 0.77.

\section{CONCLUSION}

It could be concluded that $35 \%$ and $30 \%$ crude protein level was the best under composition of diet ((50 AP: $50 \mathrm{PP})$ in terms of growth performance, feed utilization and economical evaluation under this experimental conditions.

Table 6. Economical evaluation of protein levels and source of bayad fingerlings throughout the experimental period (70 days).

\begin{tabular}{|c|c|c|c|c|}
\hline Protein level & \multicolumn{2}{|c|}{ 30 \% } & \multicolumn{2}{c|}{ 35\% } \\
\hline Treatments & 50 AP: 50 PP & 33 AP: 67 PP & 50 AP: 50 PP & 33 AP: 67 PP \\
\hline Feed intake & 119.35 & 96.08 & 130.26 & 123.2 \\
\hline feed cost /kg L.E & 8.87 & 7.73 & 12.53 & 10.70 \\
\hline $\begin{array}{c}\text { Relative to feed cost } \\
\text { L.E/ fish 1 }\end{array}$ & 70.79 & 61.69 & 100 & 85.39 \\
\hline Final weight & 61.77 & 49.77 & 69.96 & 61.29 \\
\hline Price of fish sold $^{2}$ & 2.16 & 1.74 & 2.45 & 2.15 \\
\hline Net returne & 1.10 & 0.97 & 1.20 & 1.07 \\
\hline
\end{tabular}

\section{REFERENCES}

A.O.A.C. (2012). Official Methods of Analysis. S. Williams (Ed). Association of Official Analytical Chemists, Inc. Arlington, Virg. U.S.A.
Adakole, J. A., (2000). The effects of diuretic, agricultural and industrial effluents on the water quality and Biota of Bindare stream, ZariaNigeria. Unpublished Ph.D Thesis. Ahmadu Bello University Zaria Nigeria $256 \mathrm{pp}$.

Agbo, N.W., Amisah, S., Tettey, E. and Frimpong, E.A. (2014). Effects of dietary protein levels on growth performance of claroteid catfish, Chrysichthys nigrodigitatus, fingerlings. Annals of Biological Research, 5 (4): 17-22. www.scholarsresearchlibrary.com

Fayoum J. Agric. Res. \& Dev., Vol. 34, No.2 July, 2020 
Athar M. Qurany et al.,

Ahmad, M.H. (2000). Improve productive performance in fish. Ph.D. Dissertation, Animal Prod. Department, Faculty of Agriculture, Zagazig University.

Alhassan, E.H. and Ansu-Darko, M. (2011). Food and feeding habits of a potential aquaculture candidate, the Black nile catfish, Bagrus bajadin the Golinga Reservoir. Australian Journal of Basic and Applied Sciences, 5: 354-359.

Anguas-Vélez, B.H., Civera-Cerecedo, R., Cadena-Roa, M., Guillaume, J., Martinez-Diaz, S.F. (2000). Studies on the nutrition of Spotted sand bass Paralabrax maculatofasciatus: Effect of the dietary protein level on growth and protein utilization in juveniles fed semi purified diets. Journal of World Aquaculture Society, 31: 580-591.

Auta, J. (1993). Water Quality Management in Fish Ponds. In Oniye JS, Bolorunduro PI, Auta J (Edn.) Proceedings of National Workshop on Fisheries Extention Delivery. NAERLS, ABU Zaria (pp. 1-20).

Condrey, R.E. (1982). Ingestion-limited growth for aquatic animals: the case for blackman kinetics. Canadian Journal of Fisheries and Aquatic Science, 39: 1585-1595.

Diyaware, M.Y., Modu, B.M. and Yakubu, U.P. (2009). Effect of different dietary protein levels on growth performance and feed utilization of hybrid catfish (Heterobranchus bidorsalis x Clarias anguillaris) fry in north-east Nigeria. African Journal of Biotechnology, 8 (16): 3954-3957.

El-Drawany, M.A. and Elnagar, W.G. (2015). Growth, food and feeding habits of Bagrus bayad and Bagrus docmac inhibiting Muess channel, Sharkia province, Egypt. Journal of Research and Development, 6 (7): 348 pp.

Fagbenro, O.A. (2007). Quantitative dietary protein requirements of Clarias isheriensis (Sydenham 1980) (Clariidae) fingerlings. J. Appl. Ichthyol., 8: 164-169.

Fagbenro, O.A., Balagon, A.M. and Anyanwu, C.N. (1992). Optimum dietary protein level of Heterobranchus bidorsalis fed compounded diet. Nig. J. Appl. Fish. Hydrobiol., 1: 41-45.

GAFRD (2017). General Authority for Fish Resources Development Annual fishery statistics report. Ministry of Agriculture Publications, Cairo, Egypt

Gatlin, D.M. and Hardy, R.W. (2002). Manipulations of diets and feeding to reduce losses of nutrients in intensive aquaculture. In: Aquaculture and the Environment in the United States (ed. by J.R. Tomasso), pp. 155165. World Aquaculture Society, Baton Rouge, LA,USA.

Giri, S.S., Sahoo, S.K., Paul, B.N., Mohanty, S.N. and Sahu, A.K. (2011). Effect of dietary protein levels on growth, feed utilization and carcass composition of endangered bagrid catfish Horabagrus brachysoma (Gunther 1864) fingerlings. Aquaculture Nutrition, 17: 332-337.

Giri, S.S., Sahoo, S.K., Sahu, A.K. and Meher, P.K. (2003). Effect of dietary protein level on growth, survival, feed utilization and body composition of hybrid Clarias catfish (Clarias batrachus $\times$ Clarias gariepinus). Anim. Feed Sci. Technol., 104: 169-178.

Fayoum J. Agric. Res. \& Dev., Vol. 34, No.2 July, 2020 
EFFECT OF PROTEIN LEVELS AND SOURCES ON

Giri, S.S., Sahoo, S.K., Sahu, A.K. and Mukhopadhyay, P.K. (2000). Growth, feed utilization and carcass composition of catfish Clarias batrachus (Linn.) fingerlings fed on dried fish and chicken viscera incorporated diets. Aquacult. Res., 31: 767-771.

Goda, A.M., El-Haroun, E.R. and Kabir-Chowdhury, M.A. (2007). Effect of totally or partially replacing fish meal by alternative protein sources on growth of African catfish Clarias gariepinus (Burchell, 1822) reared in concrete tanks. Aquaculture Research, 38: 279-287.

Hardy, R.W. and Tacon, A.G.J. (2002). Fish meal: historical uses, production trends and future outlook for sustainable supplies. In: Responsible Marine Aquaculture (ed. by R.R. Stickney \& J.P. McVey), pp. 311-325. CABI Publishing, Wallingford, UK.

Jamabo, N.A. and Alfred-Ockiya, J.F. (2008). Effects of dietary protein levels on the growth performance of Heterobranchus bidorsalis (Geoffrey-SaintHillarie) fingerlings from Niger delta. Afr. J. Biotechnol., 7(14): 24832485.

Jantrarotai, W., Sitasit, P. and Rajchapadee, S. (1994). The optimum carbohydrate to lipid ratio in hybrid Clarias catfish (Clarias macrocephalus $\times$ Clarias gariepinus) diets containing raw broken rice. Aquaculture, 127: 61-68.

Jauncey, K. (1982). The effects of varying dietary protein level on the growth, food conversion, protein utilization and body composition of juvenile tilapias (Sarotherodon mossambicus). Aquaculture, 27: 43-54.

Kaushik, S. J. and Medale, F. (1994). Energy requirements, utilization and dietary supply to salmonids. Aquaculture, 124: 81-97.

Keremah, R.I. and Beregha, O. (2014). Effect of varying dietary protein levels on growth and nutrient utilization of African catfish Clarias gariepinus fingerlings. Journal of Experimental Biology and Agricultural Sciences, 2(1): 13-18

Khan, M.S., Ang, K.J. and Ambak, M.A. (1996). The effect of varying dietary protein level on the growth, food conversion, protein utilization and body composition of tropical catfish Mystus nemurus (C. \& V.) cultured in static pond water system. Aquacul. Res., 27: 823-829.

Khan, M.S., Ang, K.J., Ambak, M.A. and Saad, C.R. (1993). Optimum dietary protein requirement of a Malaysian freshwater catfish, Mystus nemurus. Aquaculture, 112: 227-235.

Kokou, F., Rigos, G., Henry, M., Kentouri, M. and Alexis, M. (2012). Growth performance, feed utilization and non-specific immune response of gilthead Sea bream (Sparus aurata L. ) fed graded levels of a bioprocessed soybean meal. Aquaculture 364-365, 74-81.

Li, M. and Lovell, R.T. (1992). Growth, feed efficiency and body composition of second- and third-year channel catfish fed various concentrations of dietary protein to satiety in production ponds. Aquaculture, 103: 153163.

Fayoum J. Agric. Res. \& Dev., Vol. 34, No.2 July, 2020 
Athar M. Qurany et al.,

Li, M.H., Robinson, E.H., Peterson, B.C. and Bates, T.D. (2008). Growth and feed efficiency of juvenile Channel catfish reared at different water temperatures and fed diets containing various levels of fish meal. North Am. J. of Aquacult., 70: 347-352.

Lochnmann, R.T. and Phillips, H. (1994). Dietary protein requirement of juvenile golden shiner (Notemigonus crysoleucas) and goldfish (Carassius auratus) in aquaria. Aquaculture, 128: 277-285.

Lovell, R.T. (1988). Use of soybean meal in diets for aquaculture species. Journal of Aquatic Production, 2: 27-52.

Malami, G.Z. and Magawata, I. (2010). Analysis of food and feeding habits of Catfish (Bagrus bayad, Macropterus (Daget) in River Rima and Goronyo Dam, in Sokoto State, Nigeria. Nigerian Journal of Basic and Applied Science, 18 (2): 277 - 284.

Martinez-Palacios, C.A., Harfush-Melendez, M. and Chavez-Sanchez, C. (1996). The optimum dietary protein level for the Mexican cichlid Cichlasoma urophthalmus (Gunther): a comparison of estimates derived from experiments using fixed-rate and satiation feeding. Aqua. Nutr., 2: 11-20.

Martinez-Palacios, C.A., Rios-Duran, M.G., Ambriz-Cervantes, L., Jauncey, K.J. and Ross, L.G. (2007). Dietary protein requirement of juvenile Mexican Silverside (Menidia estor Jordan 1979), a stomachless zooplanktophagus fish. Aquacult. Nutr., 13: 304-310.

Mohanty, S.S. and Samantaray, K. (1996). Effect of varying levels of dietary protein on the growth performance and feed conversion efficiency of snakehead Channa striata fry. Aquaculture Nutrition, 2: 89-94.

Moore, B.J., Hung, S.S.O. and Medrano, J.F. (1988). Protein requirement of hatchery-produced juvenile white sturgeon (Acipenser transmontanus). Aquaculture, 71: 235-245.

Ng, H.H. and Kottelat, M. (2013). Revision of the Asian Catfish genus hemibagrus bleeker, 1862 (teleostei: Siluriformes: Bagridae). The Raffles Bulletin of Zoology, 61 (1): 205 - 291.

Ng, W.K., Soon, S.C. and Hashim, R. (2001). The dietary protein requirement of a bagrid catfish, Mystus nemurus (Cuvier \& Valenciennes), determined using semipurified diets of varying protein level. Aquac. Nutr., 7: 45-51.

NRC (1993). Nutrient requirements of fish. National Research Council National Academy Press, Washington D.C., USA.

Obasa, S.O. and Faturoti, E.O. (2000). Dietary protein requirement of brackish water catfish Chrysichthys walker fingerlings. J. Field Aquat. Stud., 1(1): $1-6$.

Otisi, A.O.A. and Ufodike, E.B.C. (1986). Growth and Survival of snakehead (Channa obscura) fed starter diets of different protein sources. Nigerian Journal of Applied Fisheries and Hydrobiology, 1: 21-24.

Pandian T.J. (1967) Intake, digestion, absorption and conversion in the fishes Megalopes cyprinoides and Ophiocephalus striatus. Marine Biology $1: 16-23$.

Fayoum J. Agric. Res. \& Dev., Vol. 34, No.2 July, 2020 
EFFECT OF PROTEIN LEVELS AND SOURCES ON

Pillay, T.V.R. (1990). Aquaculture: Principles and practices. Fishing News Book. Blackwell Scientific Publications, Ltd., Oxford, UK. pp. 575.

Refstie, S., Helland, S. and Storebakken, T. (1997). Adaptation to soybean meal in diets for rainbow trout (Oncorhynchus mykiss). Aquaculture, 153: 263-272.

Refstie, S., Roem, A.J. and Storebakken, T. (1998). Feed consumption and conversion in Atlantic salmon (Salmo salar) fed diets with fish meal, extracted soybean meal or soybean meal with reduced content of oligosaccharides, trypsin inhibitor, lectine and soya antigens. Aquaculture, 162: 301-312.

Reis, L.M., Reutebuch, E.M. and Lovell, R.T. (1989). Protein- to-energy ratios in production diets and growth, feed conversion and body composition of channel catfish, Ictalurus punctatus. Aquaculture, 77: 21-27.

Risch, L.M. (986). Bagridae: in Check-List of the freshwater fishes of Africa. Daget, J.; Gosse, J.P. and D.F.E. Thys van den Audenaerde (eds.). ISNB, Brussels; MRAC, Tervuren; and ORSTOM, Paris., 2: 2-35.

Rumsey, G.L., Haghes, S.G. and Winfree, R.A. (1993). Chemical and nutritional evaluation of soya protein preparation as primary nitrogen source for rainbow trout (Oncorhynchus mykiss). Animal Feed ScienceTechnology, 40: $135-151$.

San-Min, T. and Tae-Jun, L. (2005). Effects of dietary protein and energy levels on growth and lipid composition of juvenile snail. J. Shell Fish. pp. 5065 .

Shearer, K.D. (1994). Factors affecting the proximate composition of cultured fishes with emphasis on salmonids. Aquaculture, 119: 63-88.

Smith, R.R. (1989). Nutritional energetics. In Halver JE (Ed) Fish nutrition. 2nd Edition, Academic Press Inc. California, pp. 1-29.

SPSS. (2008). Statistical Package For Social Science (for Windows). Release 17 Copyright (C), SPSS Inc., Chicago, USA.

Ufodike, E.B.C. and Matty, A.J. (1983). Growth responses and nutrient digestibility in mirror carp (Cyprinus carpio) fed different levels of cassava and rice. Aquaculture, 31: 41-50.

Venou, B., Alexis, M.N., Fountoulaki, E. and Haralabous, J. (2006). Effects of extrusion and inclusion level of soybean meal on diet digestibility, performance and nutrient utilization of gilthead Sea bream (Sparus aurata). Aquaculture 261, 343-356.

Warren, C.E. and Davis, G.E. (1967). Laboratory studies on the feeding, bioenergetics and growth of fish. In Gerking, S.D. (Ed) The Biological Basis of Freshwater Fish Production, Blackwell, Oxford, UK, pp. 175214.

Fayoum J. Agric. Res. \& Dev., Vol. 34, No.2 July, 2020 
تاثير التداخل بين نسبة ومصدر البروتين على أداء النمو ومعدل البقاء وكفاءة الاستفادة من الغذاء

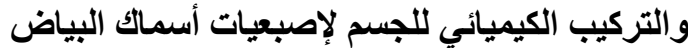

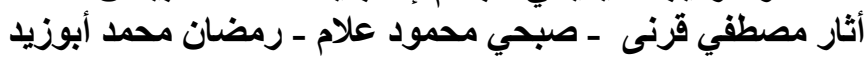

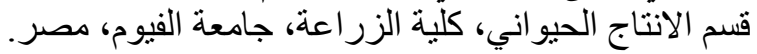

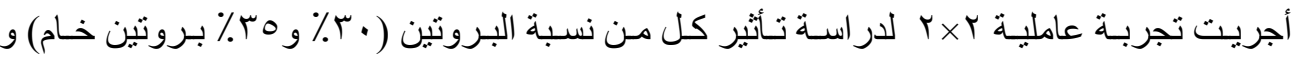

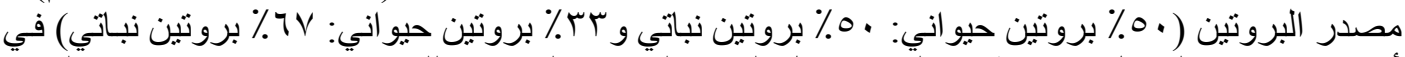

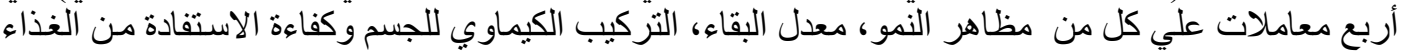

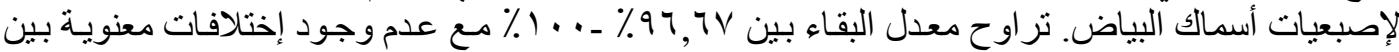

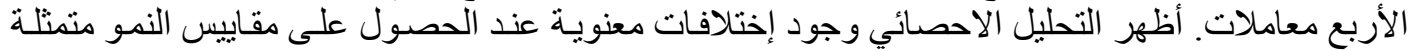

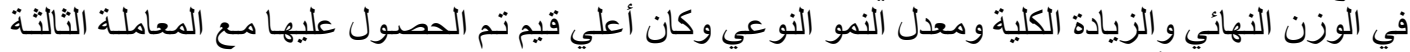

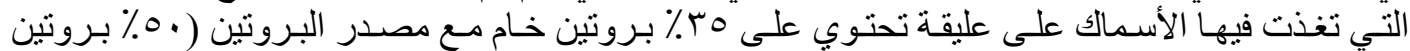

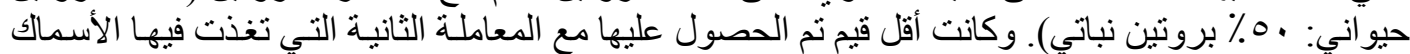

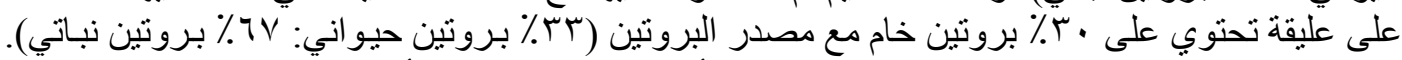

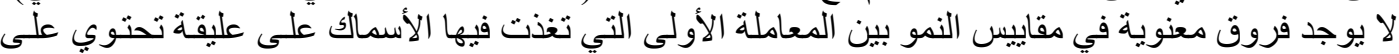

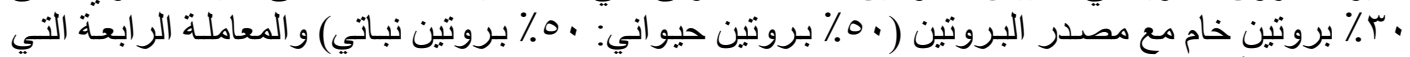

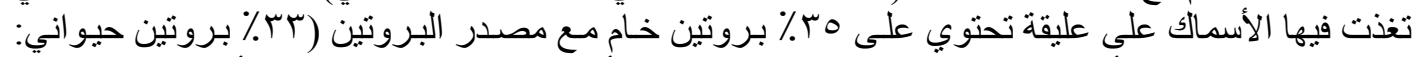

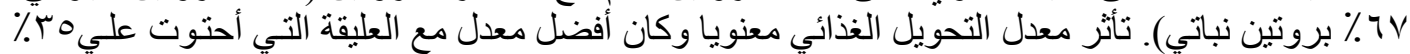

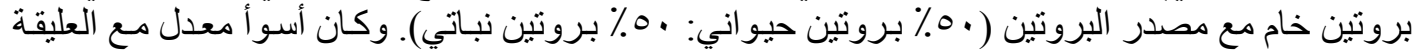

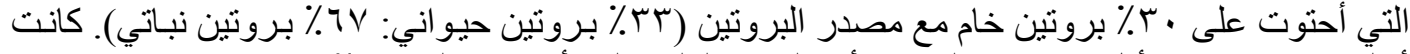

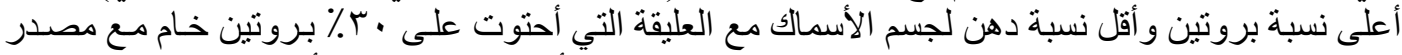

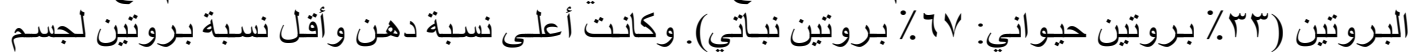

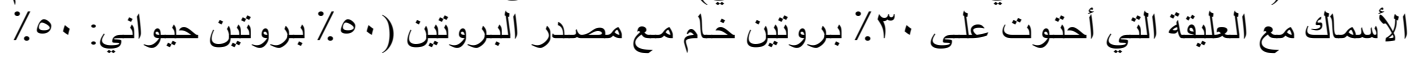

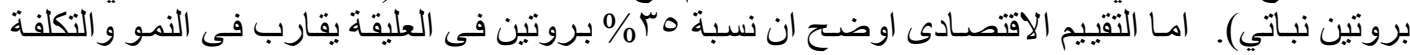

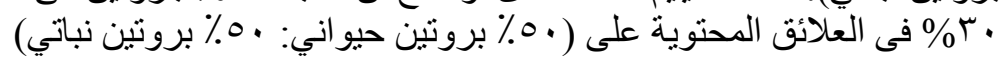

Fayoum J. Agric. Res. \& Dev., Vol. 34, No.2 July, 2020 